\title{
A Review on Bamboo as an Adsorbent for Removal of Pollutants for Wastewater Treatment
}

\author{
Junidah Lamaming $\mathbb{D}$, Sariah Saalah, Mariani Rajin, Noor Maizura Ismail, \\ and Abu Zahrim Yaser (iD
} Chemical Engineering Program, Faculty of Engineering, Universiti Malaysia Sabah, Jalan UMS, Kota Kinabalu 88400,
Sabah, Malaysia

Correspondence should be addressed to Junidah Lamaming; junidah@ums.edu.my and Abu Zahrim Yaser; zahrim@ums.edu.my Received 16 August 2021; Revised 13 January 2022; Accepted 17 January 2022; Published 2 February 2022

Academic Editor: Ho SoonMin

Copyright ( $) 2022$ Junidah Lamaming et al. This is an open access article distributed under the Creative Commons Attribution License, which permits unrestricted use, distribution, and reproduction in any medium, provided the original work is properly cited.

\begin{abstract}
Water and wastewater treatment are very important for obtaining clean and sanitary water as well as protecting the environment from toxic pollutants. Not only enriched with cellulose and carbon but the abundant resources of bamboo also make it suitable to be utilized as an adsorbent. With the right processing technologies and improvements, the potential of bamboo is unlimited. This study review provides knowledge on the use of bamboo-based adsorbents for the removal of contaminants and pollutants in wastewater in the form of activated carbon, biochar, and aerogel. This review highlighted bamboo utilization and its relevance as an adsorbent for wastewater treatment. The technologies for the processing and improvement of bamboo as well as the performance of the bamboo-based adsorbents are also discussed in this study. The adsorption capacity of bamboo has shown improvement with modification and good adsorption capacity achieved with some of the adsorbent being able to be recycled and reused.
\end{abstract}

\section{Introduction}

In the Fourth Industry Revolution (Industry 4.0) era of rapid development and industrialization, notable environmental issues, particularly water pollution, have emerged as a serious problem. This has resulted in a decrease in water quality, owing to the introduction of contaminants such as organic micropollutants and inorganic heavy metal ions. Every year, a million tons of microcontaminants such as pharmaceuticals, hormones, synthetic chemicals, pesticides, and flame retardants are expected to be released into natural water via drainage. However, removal of these contaminants necessitates the use of cost-effective technologies $[1,2]$. In accordance with the adoption of the circular economy into the wastewater sector, the system was reinvented to meet the sustainable development goals (SDG) of increasing water-use efficiency while ensuring a sustainable supply of freshwater. As a result, over the last few decades, a variety of techniques for dealing with wastewater treatment have been developed.
Bamboo utilization as a wood substitute in traditional and industrial applications raises the demand for bamboo $[3,4]$. Bamboo takes 5-12 years to fully mature, making it one of the fastest growing renewable resources [5]. According to the report by Grand View Research [6], the global bamboo market was worth 68.8 billion USD in 2018 and is predicted to increase at a compound annual growth rate of $5.0 \%$ between 2019 and 2025. Bamboo, which is viewed as a sustainable, low-cost, and abundantly available resource, is suitable for use as an adsorbent [7]. It is also high in carbon content and fibrovascular bundles. The structure of bamboo consists of epidermis, parenchyma cells, and vascular bundles, which are surrounded by supporting fibers. The unique mechanical properties of bamboo fibers come from their composite structure, in which cellulose fibrils are surrounded by a matrix of mainly lignin and hemicellulose (Figure 1) [8].

Utilization of bamboo as a raw material for wastewater treatment has been increasing in recent years. Researchers 


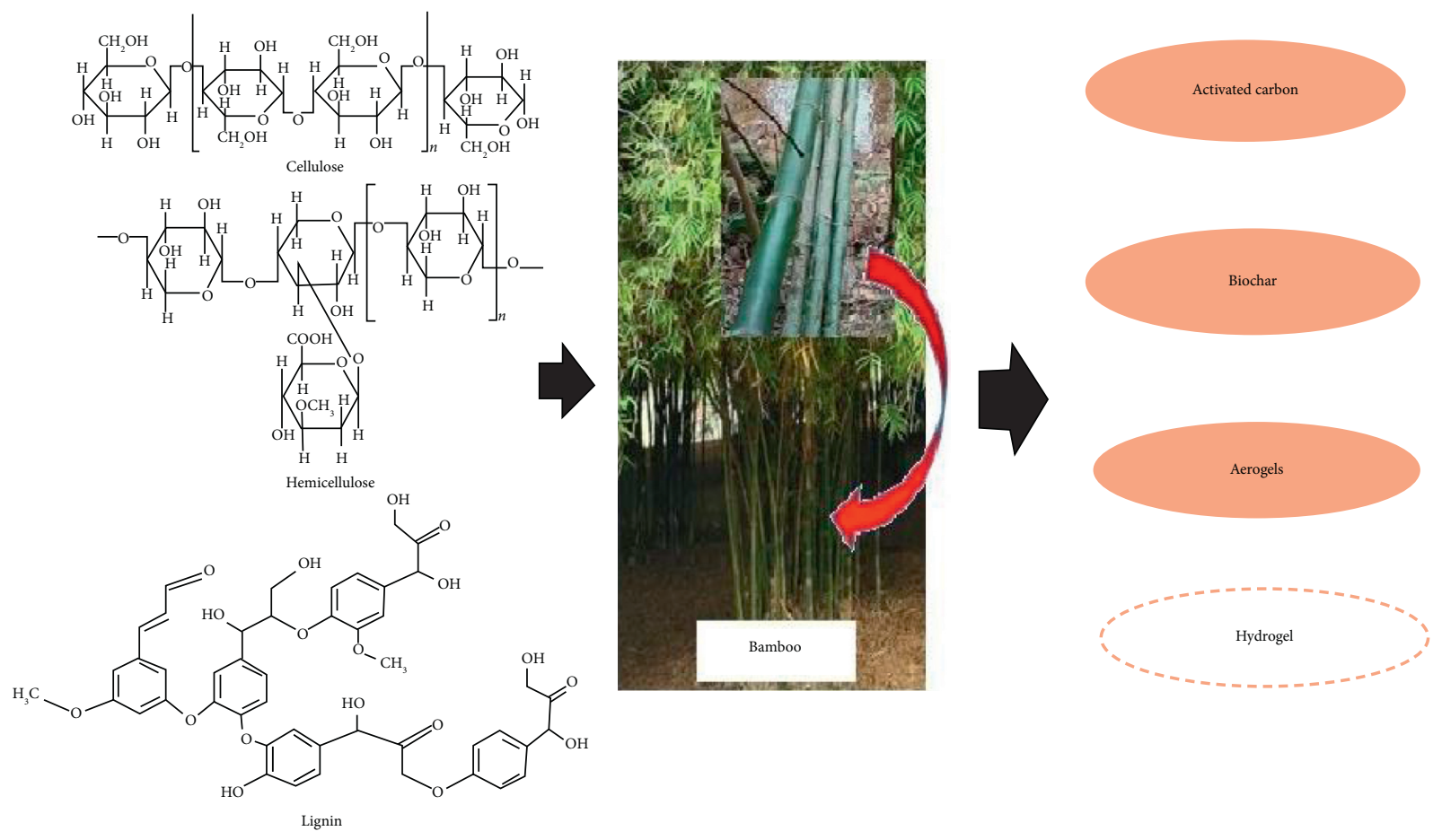

FIgURE 1: Bamboo main compositions and its application.

have developed a variety of adsorbents derived from bamboo, including bamboo-activated carbon [9-11], bamboo biochar [12-14], and bamboo aerogel [15-17] among others. The species of bamboo used as raw materials include Bambusa vulgaris, Moso, Ma, and Gigantochloa albociliata. There are numerous carbon sources that can be derived from agricultural waste, but bamboo-based adsorbents are particularly notable due to their exceptional surface area to mass ratio, which allows them to absorb a wide range of materials, chemicals, minerals, humidity, odors, and even electromagnetic waves [18].

Currently, adsorption is considered a sustainable, versatile, and effective technology for removing various contaminants and pollutants from water and wastewater treatment. The success of the technique largely depends on the development of an efficient adsorbent $[2,19]$. Adsorption is a process in which pollutants are adsorbed onto a solid surface by physical forces and sometimes, weak chemical bonds. Intermolecular forces of attraction enable some of the solute molecules from the solution to be absorbed or deposited on the solid surface when a solution containing an absorbable solute comes into contact with a solid having a highly porous surface structure [20]. The pollutant adhered to the solid surface is called an adsorbate, while the solid surface is known as the adsorbent. Adsorption is considered one of the suitable water treatment methods due to its ease of operation and the availability of a wide range of adsorbents $[21,22]$. However, adsorption has certain limitations in commercial levels of water purification as there are fewer adsorbents that have high adsorption capacities.

A good adsorbent should have a porous structure with a high surface area to increase adsorption rate, and the time required to reach adsorption equilibrium should be short so that contaminants can be removed much faster [23, 24]. Temperature, adsorbent nature, and the presence of other pollutants, as well as experimental settings and parameters such as $\mathrm{pH}$, pollutant concentration, contact time, particle size, and temperature, all affect adsorption performance in contaminant removal $[20,25]$. Because of its good adsorption capacity, active free valencies, high surface area, porous structure, surface reactivity, inertness, and thermal stability, activated carbon is a favored choice among all [26]. Activated carbon has several notable advantages, including lower operating costs, a large surface area, substantial stability, and surface and structural tunability [27]. Biochar can be used as an alternate option and precursor of value-added activated carbon for wastewater treatment and is among the most extensively used biochangers [28]. Biochar is a stiff amorphous carbon matrix residue that results from the thermal decomposition of lignin and hemicellulose after they have lost a significant amount of mass in the form of volatiles [29]. Meanwhile, aerogels are a type of three-dimensional material having an open, highly porous, and airfilled structure, as well as low density, thermal conductivity, a high degree of porosity, and a large specific surface area [30]. All of these adsorbents have the potential to remove pollutants and contaminants from wastewater.

Uncontrollable amounts of unutilized bamboo due to faster growth and excessive bamboo residue from the manufacturing process, on the other hand, frequently contribute to environmental problems [31, 32]. As a result, more research is required to be carried out to investigate other potential uses of bamboo. A few reviews have been published on the methods and technologies for the removal of pollutants or contaminants from wastewater $[33,34]$ and 
other agricultural biomass adsorbents $[2,19,35]$. However, a review that compiled bamboo as an absorbent is still lacking and limited. Therefore, this review will look at the use of bamboo as an adsorbent in recent years in various types, such as activated carbon, biochar, and aerogel. This study reviews and highlights selected studies on the performance of bamboo adsorbent as a multiadsorbent in removing contaminants and pollutants from wastewater in recent years.

\section{Review Methodology}

Publications and references used were screened and collected from the Scopus scientific database. Important searches from the years 2013-2021 with the keywords "bamboo," "adsorbents," and "wastewater" produced 85 articles. Additional searches on specific keywords "bamboo activated carbon,, "bamboo biochar," and "bamboo aerogel" generated 532 articles, 456 articles, and 45 articles, respectively. The articles were screened and narrowed down by title and abstract reading. Further screening was carried out by reading the full articles to ensure the scope was related to the review, and a total of 101 articles (34 activated carbons, 35 biochar, 15 aerogels, and 17 bamboo-related) were selected for this review. This review article consists of information from various publications including review articles, journal articles, book chapters, and conference proceedings. Several articles that were published before 2013 were also used as supporting materials and arguments in the review articles.

\section{Activated Carbon}

Activated carbon (AC) is a highly porous carbonaceous material produced from any carbon source with a large internal surface area that contains functional groups that have adsorption affinity for various contaminants [11,36]. Activated carbon can be made from biomass as well as other carbonaceous materials such as fossil, waste, or renewable sources which activated using chemical activation (such as acid, base, or salt activation) or physical activation (steam/ air/gas). The structural properties of ACs determine their adsorptive capacities. For smaller molecules, ACs with a greater specific surface area and a smaller micropore $(2 \mathrm{~nm})$ size will have better adsorption ability, whereas mesopores $(2-50 \mathrm{~nm})$ with larger molecules will have better adsorption capacity [37].

Activated carbon derived from bamboo has become a notable and promising adsorbent in wastewater treatment. Bamboo ACs can be prepared using one-step or two steps. The common method which is two steps are carbonization and activation. Carbonization was conducted in an inert atmosphere using pyrolysis/gasification at controlled high temperatures to remove volatile matter [38] and activated using physical or chemical activation. The activation process is needed to increase pore volume and diameter, as well as surface area. In addition, the suitable selection of precursors, carbonization process, and optimum activation conditions are the most essential parameters in enhancing and maximizing the adsorption capabilities of ACs for the removal of organic, inorganic, and contaminants from water and air [35]. When compared to the physical method, the chemical activation method typically has a higher carbon yield and better pore structure.

Researchers have studied ACs from bamboo for the removal of pesticides, heavy metals, and dyes in wastewater. The pores in bamboo-activated carbon are relatively large, making it suitable for the adsorption of larger molecules. Mahanim et al. [39] reported that the activated carbon prepared from bamboo exhibited good surface characteristics and porosity properties. The study found that activation time and temperature for bamboo-activated carbon are very important, and the best conditions are at $120 \mathrm{~min}$ and $800^{\circ} \mathrm{C}$, respectively. The BET (Brunauer-Emmet-Teller) surface area of activated carbon will increase with increasing activation temperature. High BET surface area means high adsorption capacity [40, 41].

Santana et al. [11] conducted a test to evaluate the adsorption abilities of ACs in removing pesticide in water treatment. The bamboo was impregnated with phosphoric acid at $80^{\circ} \mathrm{C}$ for $2 \mathrm{~h}$ before undergoing simultaneous physical and chemical activation. The activation process occurred at $500^{\circ} \mathrm{C}$, with a $10^{\circ} \mathrm{C} / \mathrm{min}$ heating rate, $60 \mathrm{~min}$ residence time with a $100 \mathrm{~mL} / \mathrm{min}$ steam water flux, and $80 \mathrm{~mL} / \mathrm{min} \mathrm{ni-}$ trogen flux. The adsorption of bamboo-activated carbon was tested with various pesticides, including furadan, metribuzin, and 2,4-dichlorophenoxyacetic acid. In their study, the ACs did not have the largest BET surface area when compared to other types of activated carbon from other biomass in various research studies [42-44]. However, it does have the highest adsorption capacities and is more effective at pesticide removal of furadan $(868.98 \mathrm{mg} / \mathrm{g})$, metribuzin $(756.47 \mathrm{mg} / \mathrm{g})$, and 2,4-dichlorophenoxyacetic acid $(274.70 \mathrm{mg} / \mathrm{g})$, as given in Table 1 . The structure of the raw material has a strong influence on the best parameters needed to obtain a specific AC. By varying the activation conditions, it is possible to obtain AC with different pore textures by optimizing their production for a specific purpose.

Lo et al. [10] conducted an experiment to test the adsorption capacity and removal efficiency of heavy metals $\left(\mathrm{Pb}^{2+}, \mathrm{Cu}^{2+}, \mathrm{Cr}^{3+}\right.$, and $\left.\mathrm{Cd}^{2+}\right)$ using two species of bamboo, which are Moso bamboo and Ma bamboo. The ACs were both carbonized at $800^{\circ} \mathrm{C}$ for $1 \mathrm{~h}$ under nitrogen at a rate of $500 \mathrm{ml} / \mathrm{min}$. The sample groups were then activated by deionized water at a rate of $400 \mathrm{ml} / \mathrm{h}$. The additional samples (Ma and Moso bamboo carbonized at $600^{\circ} \mathrm{C}$ ) were subjected to the recarbonization process (twice-activated bamboo carbon) using the same previous carbonization condition. The findings in Table 1 showed that the adsorption rate of ACs has increased after the two times of activation. In addition, a higher specific surface area, micropore area, micropore volume, and pore volume were observed for the twice-activated bamboo carbons. This may be due to the activation that occurs early in the process, allowing for the opening of rudimentary pores created during pyrolysis and the formation of additional pores. Pore widening becomes the dominating effect as the activation process progresses, whereas pore-deepening and new pore creation become 


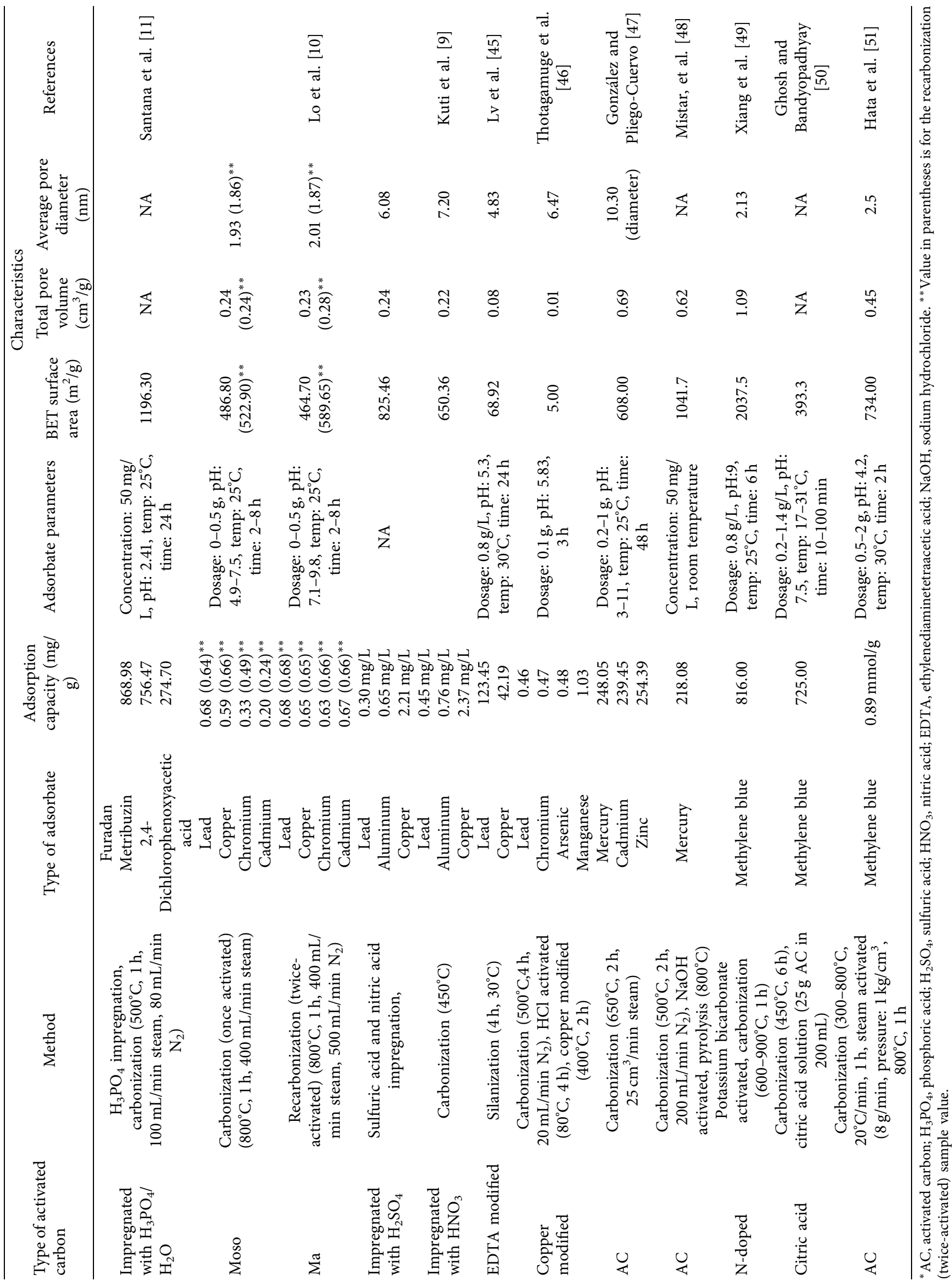


minor activities $[52,53]$. The adsorption capacity of heavy metal ions is higher in Ma bamboo ACs compared to Moso bamboo ACs. This is likely due to the fact that Ma bamboo carbons had a greater specific surface area, micropore area, and pore volume than Moso bamboo carbons. The study concluded that the optimum conditions for Ma bamboo ACs are 7.10-9.82 for $\mathrm{pH}$ and $1 \mathrm{~h}$ soaking time for the tested heavy metal ions. Other studies found that the removal efficiency of hazardous metals $(\mathrm{As}, \mathrm{Pb}$, and $\mathrm{Cr}$ ) works well at $\mathrm{pH} 5.83$, with a percentage removal of above 96\% [46].

On the other hand, Kuti et al. [9] conducted a test using ACs that were impregnated with nitric acid $\left(\mathrm{HNO}_{3}\right)$ and sulfuric acid $\left(\mathrm{H}_{2} \mathrm{SO}_{4}\right)$. The adsorption capacity of ACs impregnated with $\mathrm{H}_{2} \mathrm{SO}_{4}$ is greater than that of $\mathrm{HNO}_{3}$, as given in Table 1. ACs impregnated with sulfuric acid removed $65 \%$ of lead $(\mathrm{Pb}), 47 \%$ of aluminum $(\mathrm{Al})$, and $37 \%$ of copper $(\mathrm{Cu})$ from surface water, whereas ACs impregnated with nitric acid removed $47 \%$ of lead $(\mathrm{Pb}), 38 \%$ of aluminum $(\mathrm{Al})$, and $32 \%$ of copper $(\mathrm{Cu})$. This is attributed to the higher surface area and total pore volume of ACs impregnated with $\mathrm{H}_{2} \mathrm{SO}_{4}$ compared to $\mathrm{HNO}_{3}$. It contradicts with the study of Ademiluyi and David-West [54] who found that activation of bamboo with $\mathrm{HNO}_{3}$ together with high pore volume and low ash content is better due to the cellulose nitrite generated during the activation process, which forms more active reaction sites for adsorption of different metal ions as compared to other acids. The removal of $\mathrm{Pb}$ (II) and $\mathrm{Cu}$ (II) has increased with modification. AC functionalized with ethylene diamine tetraacetic acid (EDTA) was developed by $\mathrm{Lv}$ et al. [45] using the silanization method via tetraethyl orthosilicate (TEOS) as the cross-linker. Using EDTA as a complexing agent may produce adsorbents with strong metal-complexing properties and reserve the properties after regeneration. In addition, the modified AC had an excellent reusability with about a $40 \%$ decline in the adsorption capacity for $\mathrm{Pb}$ (II) after fifth reuses.

The mesoporous ACs created by the bamboo species Bambusa vulgaris striata have been investigated as an adsorbent for the removal of the $\mathrm{Cd}(\mathrm{II}), \mathrm{Hg}(\mathrm{II})$, and $\mathrm{Zn}$ (II) in aqueous solution by González and Pliego-Cuervo [47] with ACs dosage of $0.6 \mathrm{~g} / \mathrm{L}$, a solution $\mathrm{pH}$ of 9 , and a $16 \mathrm{~h}$ equilibrium time. Cadmium, mercury, and zinc have the highest adsorption capacities at $239.45 \mathrm{mg} / \mathrm{g}, 248.05 \mathrm{mg} / \mathrm{g}$, and $254.39 \mathrm{mg} / \mathrm{g}$, respectively. Mistar et al. [48] used the same variety of bamboo for mercury adsorption in another study. The study, which used sodium hydroxide as activating agents and used a continuous system, found that the highest adsorption capacity for mercury ions at $50 \mathrm{mg} / \mathrm{L}$ concentration was $218.08 \mathrm{mg} / \mathrm{g}$, which is lower from the findings of González and Pliego-Cuervo [47]. The surface oxygenated acidic groups (SOAG) play an important role in the adsorption process. Even at high $\mathrm{pH}$ values, González and Pliego-Cuervo [47] discovered that some of the oxygenated groups (mostly carbonyl and carboxyl) improve the adsorption capacity of the AC by forming complexes and/or chelating on the surface. Due to the significant amount of carbonyl and carboxyl groups, the adsorbent surface is negatively charged. The adsorbent becomes further negatively charged at $\mathrm{pH}$ levels near to the AC's zero charge (9.9) due to the dissociation of weakly acidic oxygenation groups and the creation of cadmium-oxygen and zinc-oxygen binding sites. In the meantime, at $\mathrm{pH}$ levels below 6 , positively charged ion species will ion exchange and/or complex with SOAG. The presence of carboxylic groups on the surface of AC encourages acidic dissociation and chelating properties, resulting in complexes of adsorbed metal and functional groups.

Ma et al. [55] developed a one-step method of producing ACs through a self-activation process. The gas emitted from the biomass itself acts as an activation agent, which allows the carbonization and activation to be combined into one step. High performance ACs from bamboo with a remarkable specific surface area of $2348 \mathrm{~m}^{2} / \mathrm{g}$ were achieved at a high pyrolysis temperature of $1050^{\circ} \mathrm{C}$. When tested on the removal of dye (methylene blue) from aqueous solution, the ACs having maximum adsorption capacity ranged from $495 \mathrm{mg} / \mathrm{g}$ to $1667 \mathrm{mg} / \mathrm{g}$. The findings show that the adsorption capacity of ACs can be developed further for wastewater treatment. Meanwhile, Hata et al. [51] also developed bamboo-activated carbon using steam activation for the removal of methylene blue. The dried bamboo was carbonized in a furnace at a temperature ranging $300-800^{\circ} \mathrm{C}$ before steam was introduced for $1 \mathrm{~h}$ at a constant flow rate of $8 \mathrm{~g} / \mathrm{min}$ under pressure of $1.0 \mathrm{~kg} / \mathrm{cm}^{2}$. Their study discovered that bamboo activated at a higher temperature $\left(800^{\circ} \mathrm{C}\right)$ had a larger surface area compared to bamboo $\mathrm{AC}$ at $600^{\circ} \mathrm{C}$, which has a higher mesopore volume $\left(0.2 \mathrm{~cm}^{3} / \mathrm{g}\right.$ compared to $0.16 \mathrm{~cm}^{3} / \mathrm{g}$ ). The AC achieved a higher adsorption capacity for methylene blue at $0.89 \mathrm{mmol} / \mathrm{g}$. Steam activation not only widened char micropores, resulting in larger meso and macropore volumes of prepared activated carbons, but also increased their surface area. N-doped porous bamboo AC carbonized at high temperature by Xiang et al. [49] and citric acid treated bamboo AC by Ghosh and Bandyopadhyay [50] also showed a high adsorption capacity of $816.00 \mathrm{mg} / \mathrm{g}$ and $725.00 \mathrm{mg} / \mathrm{g}$ for the removal of methylene blue.

\section{Biochar}

Biochar is one of the potential future immobilization methods for various pollutants in liquid wastes, aqueous solutions, and even soil. Biochar is a carbon-rich substance from biomass that is synthesized in an environment with limited or without oxygen by thermos chemical decomposition [56-58]. Biochar is produced in the milder pyrolysis condition under an inert atmosphere at a low temperature $\left(<700^{\circ} \mathrm{C}\right)$. Usually, biochar has more abundant surface functional groups, mostly oxygen-containing groups such as hydroxyl and carboxylic functional groups $[59,60]$. Biochar needs additional treatment or modification to improve the surface area compared to $\mathrm{AC}$, which has a higher surface area $[28,59,61]$. Biochar can also become a precursor to activated carbon. Its worth mentioning that once biochar has been created through pyrolysis, and both chemical and physical activation processes can be used to increase its properties $[2,57,62]$.

The physical features of biochar are influenced by pyrolysis settings such as reactor type and shape, biomass type, 
feedstock particle size, chemical activation, heating rate, and residence time. According to Gramellis et al. [29], biochar production percentages vary between $10 \%$ and $35 \%$ depending on feedstock and pyrolysis conditions. A large amount of biochar is produced at low temperatures $\left(450-500^{\circ} \mathrm{C}\right)$ due to low devolatilization rates and low carbon conversion. As the temperature rises, the amount decreases due to a faster rate of thermal degradation. For bamboo biomass, pyrolysis at lower temperatures would result in a large amount of biochar, but properties such as pore structures are sufficiently developed at around $500^{\circ} \mathrm{C}$ by the complete thermal decomposition of cellulose and hemicelluloses $\left(200-500^{\circ} \mathrm{C}\right)$ and lignin $\left(<600^{\circ} \mathrm{C}\right)$ [63]. Pyrolysis enhanced the surface area and pore volumes through continuous decomposition of the organic materials such as cellulose and lignin, as well as the creation of vascular bundles or channel structure [64].

The research by Wang et al. [65] and Yang et al. [66] suggested that the pretreatment and posttreatment properties of both feedstock and biochar, respectively, may also influence biochar properties. A few reviews have addressed and discussed the methods of decomposition and characterization of biochar, as well as its use in the removal of pollutants or contaminants [67-69]. Based on the parameters affecting the biochar properties, various techniques for modifying biochar to produce novel structures and surface qualities have been developed in order to improve its remediation efficacy and environmental benefit. Table 2 provides adsorption capacities of contaminant/pollutants removal by biochar derived from bamboo.

A study by Alamin and Kaewsichan [70] has been carried out using two types of adsorbent mixtures, biochar calcium sulfate (BC) and biochar calcium sulfate hydroxyapatite $(\mathrm{BCH})$, through pyrolysis. The study was conducted for the purpose of removing 2,4-dichlorophenol (DCP) from aqueous solutions. The phenolic derivatives are largely used as intermediates in the productions of plastic, colors, pesticides, insecticides, and others, which are toxic to humans and aquatic life, carcinogenic, mutagenic, and resistant to biodegradation. The adsorption capacity for the removal of phenol employing BC was found to be $10.69 \mathrm{mg} / \mathrm{g}$ and that for $\mathrm{BCH}$ was $16.37 \mathrm{mg} / \mathrm{g}$. The adsorption was conducted over $180 \mathrm{~min}$ of operating time at varying initial 2,4-DCP solution concentrations $(5-10 \mathrm{mg} / \mathrm{L})$ and various flow rates $(0.25-0.75 \mathrm{~L} / \mathrm{min})$. The adsorption capabilities of $\mathrm{BC}$ and $\mathrm{BCH}$ were compared, and it was discovered that the two adsorbents exhibit similar isotherm and kinetics behavior. When compared to BC (10.69 mg/g), BCH performed better $(16.37 \mathrm{mg} / \mathrm{g})$. Since hydroxyapatite has good surface qualities, such as large accessible internal and exterior surfaces and a big surface area, adding it to $\mathrm{BC}$ improved the performance of the adsorbent $\mathrm{HBC}$ due to the increased specific surface area as well as more macroporous structures.

Wang et al. [14] investigated the removal ability of fluoroquinolone antibiotics using bamboo biochar. The antibiotics that enter the water poses a human health threat due to the potential development of bacterial antibiotic resistance. Through the experiment, they obtained more than $99 \%$ of the removal of the fluoroquinolone antibiotics from wastewater. The maximum adsorption capacity obtained was $45.88 \mathrm{mg} / \mathrm{g}$. The impact of the wastewater $\mathrm{pH}$ on the adsorption can be neglected since the adsorption capacities do not change when the $\mathrm{pH}$ is manipulated between 3 and 10. In another study, Huang et al. [71] found that biochar underwent ball milling that can eliminate sulphonamide antibiotics from wastewater. The biochar was pyrolyzed at three different temperatures $\left(300,450\right.$, and $600^{\circ} \mathrm{C}$ ) for $1.5 \mathrm{~h}$ in a nitrogen filled tubular furnace.

The authors found that a ball-milled biochar obtained at temperature $450^{\circ} \mathrm{C}$ has the highest and best efficiency of removal for both sulfamethoxazole (SMX) and sulphapyridine (SPY). The solution $\mathrm{pH}$ has greatly affected the sulphonamide adsorption by the electrostatic interaction. When it was tested in the sample of wastewater with $\mathrm{pH} 7.6$, the same ball-milled biochar achieved the high adsorption capacities of SMX with $25.7 \mathrm{mg} / \mathrm{g}$ and SPY with $58.6 \mathrm{mg} / \mathrm{g}$, at $\mathrm{pH}$ 6. Therefore, it can be inferred that bamboo biochar can be used for the removal of antibiotics in wastewater.

Fan et al. [75] conducted a study on removal of ammonium ions. In the study, biochar was pyrolyzed at a temperature of $370^{\circ} \mathrm{C}$ without the presence of air. Biochar was then dried at $105^{\circ} \mathrm{C}$ for $2 \mathrm{~h}$ before being heated at $500^{\circ} \mathrm{C}$ in an oven for another $8 \mathrm{~h}$ to obtain the high ash content. The ammonium ions are effectively adsorbed on the surface of the biochar with an optimum adsorption potential of $6.38 \mathrm{mM} / \mathrm{g}$. The temperature seems to affect the adsorption capacity because it shows that as the temperature increases, the adsorption capacity also increases. It is interesting to note that the high ionic strength in the sample seems to be the reason for the increase in ammonium adsorption. In another study, Qin et al. [82] also used ball-milled biochar to eliminate the ammonium out from the water. However, the study compares the ball-milled bamboo-derived biochar to a common bamboo-derived biochar using batch adsorption experiments. The study discovered that the ball-milled bamboo biochar (BMBB) has the highest capacity for the adsorption with $22.9 \mathrm{mg} / \mathrm{g}$ compared to bamboo biochar (BB) with $7.0 \mathrm{mg} / \mathrm{g}$. The ammonium adsorption onto BMBB was predominantly controlled by interactions between the ammonium and the acidic oxygen-containing functional groups because $\mathrm{BMBB}$ was rich in surface functional groups. Adsorption of ammonium onto biochar could result majorly from the chemical bonding and polar interaction between ammonium and surface functional groups. This enhanced the sorption ability of BMBB to ammonium by promoting the cation- $\pi$ interaction on the surface of biochar.

As compared to normal biochar, engineered or modified biochar possessed a larger surface area, stronger adsorption capacity, and abundant surface functional groups, enabling a new type of carbon material with great application prospects in various wastewater treatments [34]. Tang et al. [13] developed a modified biochar for the removal of cadmium ions, $\mathrm{Cd}^{2+}$. Biochar was produced from bamboo powder using $\mathrm{ZnCl}_{2}$ as a chemical activator and activated at $500^{\circ} \mathrm{C}$ or $700^{\circ} \mathrm{C}$ in nitrogen for $3 \mathrm{~h}$ in the tube furnace until modified bamboo-derived biochar was obtained. According to the author, bamboo-derived porous biochar made by $50 \% \mathrm{ZnCl}_{2}$ chemical activation of bamboo processing residues at $700^{\circ} \mathrm{C}$ 
TABLE 2: Adsorption capacities of contaminant/pollutants removal by biochar derived from bamboo.

\begin{tabular}{|c|c|c|c|c|c|c|}
\hline Type of biochar & Pyrolysis condition & Adsorbate & $\begin{array}{c}\text { Parameters } \\
\text { (concentrations, } \\
\text { temperature, time) }\end{array}$ & $\mathrm{pH}$ & $\begin{array}{l}\text { Adsorption } \\
\text { capacity } \\
(\mathrm{mg} / \mathrm{g}) \\
\end{array}$ & References \\
\hline $\begin{array}{l}\text { Calcium sulfate } \\
\text { hydroxyapatite plus } \\
\text { calcium sulfate }\end{array}$ & $500^{\circ} \mathrm{C}, 20^{\circ} \mathrm{C} / \mathrm{min}, 4 \mathrm{~h}$ & $\begin{array}{c}2,4- \\
\text { Dichlorophenol }\end{array}$ & $\begin{array}{l}5-10 \mathrm{mg} / \mathrm{L}, \text { room } \\
\text { temperature, } 3 \mathrm{~h}\end{array}$ & $\begin{array}{l}8 \\
6\end{array}$ & $\begin{array}{l}10.69 \\
16.37\end{array}$ & $\begin{array}{c}\text { Alamin and } \\
\text { Kaewsichan } \\
\text { [70] }\end{array}$ \\
\hline Unmodified & $500^{\circ} \mathrm{C}$ & $\begin{array}{l}\text { Fluoroquinolone } \\
\text { antibiotics }\end{array}$ & $500 \mathrm{mg} / \mathrm{L}, 25^{\circ} \mathrm{C}, 96 \mathrm{~h}$ & $3-10$ & 45.88 & $\begin{array}{l}\text { Wang et al. } \\
\text { [14] }\end{array}$ \\
\hline Ball milled & $\begin{array}{c}480^{\circ} \mathrm{C}, 5^{\circ} \mathrm{C} / \mathrm{min}, 2 \mathrm{~h} \\
\text { Ball milled }(300 \mathrm{rpm}, \\
12 \mathrm{~h})\end{array}$ & $\begin{array}{l}\text { Sulfamethoxazole } \\
\text { Sulphapyridine }\end{array}$ & $\begin{array}{l}3-30 \mathrm{mg} / \mathrm{L}, \text { room } \\
\text { temperature, } 24 \mathrm{~h}\end{array}$ & 6 & 58.60 & $\begin{array}{l}\text { Huang et al. } \\
\text { [71] }\end{array}$ \\
\hline $\begin{array}{l}\text { Magnetic chitosan } \\
\text { modified }\end{array}$ & $\begin{array}{c}700^{\circ} \mathrm{C}, 2 \mathrm{~h}, 100 \mathrm{~mL} / \\
\text { min } \mathrm{N}_{2} \text { magnification } \\
\text { (coprecipitation) }\end{array}$ & $\mathrm{Cr}(\mathrm{VI})$ & $0-500 \mathrm{mg} / \mathrm{L}, 25^{\circ} \mathrm{C}, 24 \mathrm{~h}$ & $2-10$ & $\begin{array}{c}75.80 \\
127.00\end{array}$ & $\begin{array}{l}\text { Zhang, } \mathrm{H} \text { et al. } \\
{[72]}\end{array}$ \\
\hline Modified EDTA-LDH & $480^{\circ} \mathrm{C}, 5^{\circ} \mathrm{C} / \mathrm{min}, 2 \mathrm{~h}$ & $\mathrm{Cr}(\mathrm{VI})$ & $\begin{array}{l}2-250 \mathrm{mg} / \mathrm{L}, \text { room } \\
\text { temperature, } 24 \mathrm{~h}\end{array}$ & 3 & 38.00 & $\begin{array}{c}\text { Huang et al. } \\
\text { [73] }\end{array}$ \\
\hline $\mathrm{HNO}_{3}$ modified & $500^{\circ} \mathrm{C} / 700^{\circ} \mathrm{C}, 3 \mathrm{~h}$ & $\mathrm{Cd}^{2+}$ & $100 \mathrm{mg} / \mathrm{L}, 35^{\circ} \mathrm{C}, 1.5 \mathrm{~h}$ & 7 & 17.29 & Tang et al. [13] \\
\hline $\begin{array}{l}\text { PEI-alkali } \\
\text { PEI-acid }\end{array}$ & $450^{\circ} \mathrm{C}, 1 \mathrm{~h}$ & $\begin{array}{l}\mathrm{U}(\mathrm{VI}) \\
\mathrm{U}(\mathrm{VI})\end{array}$ & $200 \mathrm{mg} / \mathrm{L}, 25^{\circ} \mathrm{C}, 24 \mathrm{~h}$ & 5 & $\begin{array}{l}212.70 \\
185.50\end{array}$ & Wang et al. \\
\hline Hydrous & $370{ }^{\circ} \mathrm{C}$ & Ammonium ion & $100 \mathrm{mg} / \mathrm{L}, 20^{\circ} \mathrm{C}, 12 \mathrm{~h}$ & 6.5 & $6.38 \mathrm{mM} / \mathrm{g}$ & Fan et al. [75] \\
\hline Unmodified & $1000^{\circ} \mathrm{C}$ & Acid Black 172 & $500 \mathrm{mg} / \mathrm{L}, 40^{\circ} \mathrm{C}, 8 \mathrm{~h}$ & 1 & 401.88 & Yang et al. [76] \\
\hline $\begin{array}{l}\text { PEI modified, } \\
\text { magnetic }\end{array}$ & $\begin{array}{l}\text { Magnetized by the } \\
\text { hydrothermal method }\end{array}$ & Congo red & $200 \mathrm{mg} / \mathrm{L}, 25^{\circ} \mathrm{C}, 24 \mathrm{~h}$ & 6.5 & 435.90 & Wu et al. [77] \\
\hline PEI modified & $\begin{array}{l}\mathrm{NaOH} \text { treated }\left(80^{\circ} \mathrm{C},\right. \\
4 \mathrm{~h}), \text { wet impregnation } \\
\text { method }\end{array}$ & Congo red & $400 \mathrm{mg} / \mathrm{L}, 25^{\circ} \mathrm{C}$ & 7 & 871.04 & $\begin{array}{c}\text { Zhang et al. } \\
\text { [78] }\end{array}$ \\
\hline $\mathrm{Mg}$ engineered & $600^{\circ} \mathrm{C}, 10^{\circ} \mathrm{C} / \mathrm{min}, 1 \mathrm{~h}$ & Phosphate & $\begin{array}{l}31 \mathrm{mg} / \mathrm{L} \text {, room temperature, } \\
24 \mathrm{~h}\end{array}$ & 11 & 119.6 & $\begin{array}{l}\text { Zheng et al. } \\
\text { [79] }\end{array}$ \\
\hline Fe modified & $600^{\circ} \mathrm{C}$ & Nitrogen & $\begin{array}{c}8.561-10.618 \mathrm{mg} / \mathrm{L}(\text { low } \mathrm{N}) \\
\text { and } 16.932-18.774 \mathrm{mg} / \mathrm{L} \\
(\text { high } \mathrm{N}), 19.6-25.3^{\circ} \mathrm{C} \\
12-96 \mathrm{~h}\end{array}$ & - & $128.40 \mathrm{~g}$ & Jia et al. [80] \\
\hline $\begin{array}{l}\text { Unmodified, } \\
\text { montmorillonite } \\
\text { modified }\end{array}$ & $460^{\circ} \mathrm{C}, 120 \mathrm{~min}, \mathrm{~N}_{2}$ & Nitrate & $200 \mathrm{mg} / \mathrm{L}, 25^{\circ} \mathrm{C}, 24 \mathrm{~h}$ & 4 & $\begin{array}{l}5 \\
9\end{array}$ & $\begin{array}{c}\text { Viglašová et al. } \\
{[81]}\end{array}$ \\
\hline
\end{tabular}

${ }^{*}$ Ethylenediaminetetraacetic acid (EDTA) intercalated layered double hydroxides (LDH); PEI, polyethyleneimine.

has a lower adsorption capacity of $9.42 \mathrm{mg} / \mathrm{g}$ than porous biochar produced at $500^{\circ} \mathrm{C}$, with an adsorption capacity of $10.78 \mathrm{mg} / \mathrm{g}$. Owing to its high processing temperature, biochar has fewer acid functional groups and slightly lower pore structure properties. The adsorption capacity was improved to $17.29 \mathrm{mg} / \mathrm{g}$ after further modification using $\mathrm{HNO}_{3}$ oxidation at $100^{\circ} \mathrm{C}$. Biochar achieved the best removal efficiency of $95.53 \%$ for $\mathrm{Cd}^{2+}$ with a concentration of $100 \mathrm{mg} / \mathrm{L}$ at $\mathrm{pH} 7$ and a temperature of $35^{\circ} \mathrm{C}$. The $\mathrm{Cd}^{2+}$ adsorption properties of materials after $\mathrm{HNO}_{3}$ oxidation were improved to varying extent, indicating that increasing acid groups are advantageous to improving the $\mathrm{Cd}^{2+}$ adsorption performance of materials. The adsorption capacity of $\mathrm{Cd}^{2+}$ on biochar has not decreased significantly after four adsorption-desorption recycling cycles. This is because biochar at that phase has a high adsorption capacity and good regeneration performance.

Metal-complex dyes are usually applied in the textile industry; however, their aromatic structure and heavy metal ions are detrimental to the environment and human health. Dye-containing wastewater has the potential to harm the aquatic environment by obstructing light penetration. Yang et al. [76] conducted a study on the great potential of adsorption for metal-complex dye (Acid Black 172) removal in wastewater using bamboo-derived biochar. In the study, the equilibrium, kinetics, and modelling of the artificial neural network were investigated using biochar generated by pyrolysis. The study reported that bamboo biochar was proven to be a cost-effective adsorbent for metal-complex removal from the aqueous solution. The adsorption capacity was found to be $401.88 \mathrm{mg} / \mathrm{g}$ with a $\mathrm{pH}$ of 1.0 . Throughout their study, temperature has been the major factor influencing the adsorption process, and the adsorption process was not really affected by the ionic strength.

The porous biochar modified with polyethyleneimine (PEI) was derived by Wang et al. [74] using Moso bamboo biochar through graft copolymerization. The grafting of carboxyl groups can enhance the adsorption capacity and PEI exhibits good complexation ability for U (VI) [83]. The bamboo residue was carbonized in a tubular furnace at $450^{\circ} \mathrm{C}$ for $1 \mathrm{~h}$, washed, and dried at $60^{\circ} \mathrm{C}$ for $24 \mathrm{~h}$. At a pH of 5 , the modified biochar had maximal adsorption capacities of $212.7 \mathrm{mg} / \mathrm{g}$ (PEI-alkali-biochar) and $185.5 \mathrm{mg} / \mathrm{g}$ (PEIacid-biochar), which are 9-10 times higher than pristine 
biochar. In addition, both modified biochars can be regenerated by acid elution, which keeps their high adsorption capacity after 5 adsorption-desorption cycles and has excellent reusability and stability. Other studies reported by Wu et al. [77] and Zhang et al. [78] found that using PEI magnetic biochar and PEI-modified biochar from bamboo also had superior regeneration ability and excellent adsorption capacity of $435.9 \mathrm{mg} / \mathrm{g}$ and $871.04 \mathrm{mg} / \mathrm{g}$, respectively, for Congo red. As a result, PEI-alkali and PEI magnetic and modified biochar can be considered a promising material for removing $\mathrm{U}(\mathrm{VI})$ and Congo red in real-world applications.

Apart from the excellent adsorption capacities, magnetic biochar demonstrates greater advantages over other biochar or biochar composites since they can be easily recovered from solution via magnetic separation. Zhang et al. [72] determined the maximum adsorption capacities of magnetic bamboo biochar (MBB) and chitosan-modified magnetic bamboo biochar (CMBB) for the removal of $\mathrm{Cr}(\mathrm{VI})$ at a temperature of $25^{\circ} \mathrm{C}$ to be $75.8 \mathrm{mg} / \mathrm{g}$ and $127 \mathrm{mg} / \mathrm{g}$, respectively. When compared to $\mathrm{MBB}, \mathrm{CMBB}$ is found to be more efficient because it can maintain a high removal of $\mathrm{Cr}(\mathrm{VI})(127 \mathrm{mg} / \mathrm{g})$ even at a wider $\mathrm{pH}$ range of $2-10$. Furthermore, CMBB has excellent reusability when it comes to $\mathrm{Cr}(\mathrm{VI})$ removal. Modified biochar loaded with ethylenediaminetetraacetic acid (EDTA) intercalated $\mathrm{Mg} / \mathrm{Al}$ layered double hydroxides (LDH) also showed a good removal efficiency for $\mathrm{Cr}(\mathrm{VI})$. The modified EDTA-LDH biochar was synthesized by the liquid phase coprecipitation of LDH on biochar substrates.

Engineered biochars (EBCs) were prepared by Zheng et al. [79] using bamboo where it was pretreated with magnesium $(\mathrm{Mg})$, aluminum $(\mathrm{Al})$, and salt solutions of iron $(\mathrm{Fe})$. The Al-EBCs had the best aqueous stability with almost no metal dissolution. Based on the study, all the samples of the EBCs showed an increase in $\mathrm{P}$ adsorption levels pretreatment. Both $\mathrm{Fe}$ and $\mathrm{Al}-\mathrm{EBC}$ showed a removal of up to $68 \%$ at low initial $\mathrm{P}$ concentration and $94 \%$ of $\mathrm{P}$, respectively, while $\mathrm{Mg}$-EBC achieved the highest $\mathrm{P}$ adsorption capacity with $119.6 \mathrm{mg} / \mathrm{g}$ at high $\mathrm{P}$ concentration. The result indicates that metal oxide or hydroxide-loaded EBCs are great adsorbents that can be applied.

The effectiveness of biochar as a viable material for the treatment of wastewater and linking the ability of nitrate sorption to the characteristics of the substance has been investigated by Viglašová et al. [81]. The biochar was pyrolyzed at $460^{\circ} \mathrm{C}$ for $120 \mathrm{~min}$ in a rotary furnace under nitrogen. The montmorillonite particles were evenly dispersed across the biochar surface. The adsorption studies for the removal of nitrates from aqueous solutions were investigated by a batch method at laboratory temperatures. At $\mathrm{pH} 4$, biochar had a maximum adsorption capacity of $5 \mathrm{mg} /$ $\mathrm{g}$, while modified biochar/montmorillonite had a maximum adsorption capacity of $9 \mathrm{mg} / \mathrm{g}$. Adsorption of nitrate was found to be quite fast, and after achieving equilibrium, adsorption remained nearly constant. The authors agreed with Liang et al. [84] that monolayer absorption (chemical adsorption) controlled the adsorption sample at low concentrations, whereas multilayer adsorption dominated at high concentrations (both chemical adsorption and physical absorption). The performance of bamboo-based biochar as an adsorbent for element removal is equally good, and it can be increased by applying physical or chemical activation procedures.

The most common water pollutants are nitrogen $(\mathrm{N})$ compounds that produce ammonium $\left(\mathrm{NH}_{4}^{+}\right)$and nitrate $\left(\mathrm{NO}_{3}{ }^{-}\right)$ions, which are the most widespread water contaminants. Higher concentration of ammonia-nitrogen also contributes to the pungent smell [85]. According to Chen et al. [86], $\mathrm{NO}_{3^{--}} \mathrm{N}$ is the major $\mathrm{N}$ form in wastewater treatment plant tailwater, which typically has a high total $\mathrm{N}$ (TN) concentration. Jia et al. [80] developed bamboo-derived biochar that was activated with $\mathrm{HCl}$ and loaded with $\mathrm{Fe}\left(\mathrm{FeCl}_{3} \cdot 6 \mathrm{H}_{2} \mathrm{O}\right)$ to increase microbial nitrogen removal. The highest efficiency of the removal of $\mathrm{NO}_{3}--\mathrm{N}$ was collected in Fe-modified biochar with a $96 \mathrm{~h}$ hydraulic retention time with a $95.30 \%$ removal efficiency, $\mathrm{TN}$ of $86.68 \%, \mathrm{NH}_{4}+-\mathrm{N}$ of $86.33 \%$, and $\mathrm{NO}_{2}-\mathrm{N}$ of $79.35 \%$. The increase in microbial nitrogen removal was attributed to Fe-modified biochar, which successfully removed a total of $128.40 \mathrm{~g}$ of nitrogen. Biochar in combination with $\mathrm{Fe}(\mathrm{OH})_{3}$ increased $\mathrm{NO}_{3}-\mathrm{N}$ removal while decreasing $\mathrm{N}_{2} \mathrm{O}$ emission. The activation with $\mathrm{HCl}$ increases the electrostatic adsorption of anions like $\mathrm{NO}_{3}-\mathrm{-N}$ by providing more active sites for the adsorbent particles. Therefore, Fe-modified biochar is an extremely effective system for nitrogen removal, specifically nitrate $\mathrm{N}$, apart from being more feasible.

\section{Bamboo Aerogel}

Aerogel is a gel-derived synthetic porous ultralight substance in which the liquid portion of the gel has been replaced by a gas without significant collapse of the structure of the gel [87]. The solid has extremely low thermal conductivity and low density. Aerogel contains $99.8 \%$ air. It has a porous solid network with air pockets that fill up a large portion of the space within the material. Furthermore, the preparation of aerogels from cellulose materials is simple since the cellulose chain contains many hydroxyl groups; therefore, no crosslinking agent is required throughout the process. This means that the intramolecular and intermolecular physical crosslinking of hydrogen bonds can produce a stable, threedimensional network structure, making the aerogel manufacturing procedure very easy. The chemical alteration of cellulose to improve the mechanical strength and structural features of cellulose aerogels (from hydrophilic to hydrophobic) is then relatively simple to achieve. These materials have become the most promising absorbents owing to their lightness, high porosity, and large inner surface area.

Jiao et al. [15] fabricated a lightweight and super hydrophobic carbon fiber aerogel (CFA) by using natural bamboo fiber through pyrolysis treatment under nitrogen. After removing the air using a vacuum, the sample was heated to $500^{\circ} \mathrm{C}$ for $1 \mathrm{~h}$ before the temperature was raised to $1000^{\circ} \mathrm{C}$ for $2 \mathrm{~h}$. The heating rate was set at $5^{\circ} \mathrm{C} / \mathrm{min}$. By breaking down the hydrophilic groups in cellulose-based hydrophilic materials, the treatment contributes to the 
transition to hydrophobic carbon products [88, 89]. The adsorption test was conducted to determine the adsorption capacity of the aerogel for the removal of different organic solvents and oils, as given in Table 3. The CFA has excellent adsorption recyclability and can also be reused using three simple processes, such as burning, extracting, and squeezing. Adsorption selectivity is high in CFA, with high water repellence.

A similar study was carried out by Yuan et al. [90] to develop carbon aerogels (CA) from bamboo pulp fibers. The freeze-dried pulp was heated at $240^{\circ} \mathrm{C}$ with heating rate of $2^{\circ} \mathrm{C} / \mathrm{min}$ for $1 \mathrm{~h}$ before continuing to $400^{\circ} \mathrm{C}$ for another $1 \mathrm{~h}$ and raising it to $800^{\circ} \mathrm{C}$ for $2 \mathrm{~h}$. The findings on the CA show greater adsorption capacity for removal of selected organic solvents and oils, and the CA reusability is found to be admirable. Studies by Yang et al. [91] on the developed multifunctional carbon fiber (MCF) aerogel from disposable bamboo chopsticks also show the aerogel is integrated with super hydrophobicity, mild adsorption capacity, and stable recyclability with low production cost.

$\mathrm{Xu}$ et al. [92] also developed CNFs/PVA/GO from bamboo powder cellulose nanofibers (CNFs), graphite powder (GO), and polyvinyl alcohol (PVA). While there are many excellent characteristics of CNF aerogels, their capacity and modulus are poorer than those of other inorganic substances. As a result, this study conducted a CNF-based composed of a CNF skeleton (CNFs/PVA/GO aerogel) that could overcome these disadvantages. The CNF solution, PVA solution, and GO solution were mixed together by vigorous stirring prior to adding sulfuric acid and glutaraldehyde. The freeze-dried CNF/PVA/GO carbon aerogels were fabricated through the pyrolysis process. The aerogels were heated in a tubular furnace at $200^{\circ} \mathrm{C}\left(4^{\circ} \mathrm{C} / \mathrm{min}\right)$ for $30 \mathrm{~min}$ before the temperature was raised to $600^{\circ} \mathrm{C}\left(3^{\circ} \mathrm{C} / \mathrm{min}\right)$ with a holding time of $2 \mathrm{~h}$. The produced aerogels show the efficiency of removal of different organic solvents and oils. The CNF/PVA/GO carbon aerogels express super hydrophobic properties have high absorption capacity, high absorption selectivity, flame retardancy, and good recyclability.

Furthermore, $\mathrm{Xu}$ et al. [93] used a simple dipping and carbonization procedure to create cellulose nanofibers (CNFs)/multiwalled carbon nanotubes (MWCNTs) carbon aerogels. The addition of carbon elements to aerogels during the carbonization process can enhance their dimensional stability. An ultrasonic bath and a high-speed mixer were used to treat the bamboo CNF slurry before it was poured and frozen into the required molds. The CNF aerogel is dipped into the MWCNT solution, and the weight ratio between both materials is controlled before being freezedried. The freeze-dried aerogel was heated at $500^{\circ} \mathrm{C}$ with a heating rate of $5^{\circ} \mathrm{C} / \mathrm{min}$ for $120 \mathrm{~min}$ in argon flow to obtain the CNF/MWCNT carbon aerogel (CMCA). The fabricated aerogel has low density, high porosity, is compressible, and multifunctionally hydrophobic, stable, recyclable, and lowcost production. In addition, the produced aerogels can be recycled many times by distillation and combustion, satisfying the requirements of practical oil-water separation.

Yi et al. [17] used bamboo fungus to create tubelike aerogels containing macropores (tubelike stipes with a hierarchical porous structure). The aerogel based on biomass was prepared by lyophilization and then treated with pyrolysis. Fresh bamboo fungus stipes were frozen and subsequently freeze-dried. The carbon ink was meticulously coated on the inside and outer surfaces of the freeze-dried bamboo fungus with a painting brush prior to pyrolysis in a tube furnace at $900^{\circ} \mathrm{C}\left(6^{\circ} \mathrm{C} / \mathrm{min}\right)$ for $1 \mathrm{~h}$ under argon gas. The carbonized aerogels were hydrophobically treated through chemical vapor deposition (CVD) with methyltrimethoxysilane (MTMS) in the silylation process. This tubelike aerogel offers remarkable recyclability and reusability. It facilitates the rapid and continuous flow of liquid via its hollow tubes because of its good mechanical stability, high porosity, and special morphology. It is revealed in this work that the macroscopic structure of aerogels has a major effect on both the absorption capacity and the separation speed of oil in water.

Micron-sized white bamboo fibril-based silane cellulose aerogels (MWBFs) were fabricated by Nguyen et al. [16] from white bamboo to adsorb oils. The aerogels were made from micron-sized white bamboo fibrils (MWBFs) gels in an aqueous alkali hydroxide/urea solution and then freezedried. The aerogel was then treated with a silane compound using a common chemical vapor deposition process, making it hydrophobic and oleophilic. The absorbent has an adsorption capacity ranging from $631 \%$ to $1081 \%$ by weight gain. The highly porous structure and hydrophobic silane coating of the silane-coated cellulose aerogel account for its strong oil/solvent absorption capabilities. The aerogel is also biodegradable.

For efficient $\mathrm{Pb}(\mathrm{II})$ removal from bamboo powder waste, Chen et al. [94] developed cellulose nanocrystal-g-poly (acrylic acid-co-acrylamide) aerogels. By grafting CNCs with acrylic acid (AA) and acrylamide (AM) and crosslinking with $\mathrm{N}, \mathrm{N}^{\prime}$-methylenebisacrylamide (MBA), CNC-g-P(AA/ AM) aerogels were created. The adsorbent produced a maximum $\mathrm{Pb}(\mathrm{II})$ adsorption capacity of $366.3 \mathrm{mg} / \mathrm{g}$, surpassed the pure CNC aerogel and with excellent reusability.

Wang et al. [95] developed a cellulose-based carbon aerogel for use in sewage treatment. Synthesis of cellulosebased carbon aerogels is produced by dissolution, gelation, regeneration, freeze-drying, and carbonization of cellulose. The adsorption capacity for adsorbate malachite green is $1.947 \mathrm{~g} / \mathrm{g}$ and for $\mathrm{Cu}(\mathrm{II}) 0.801 \mathrm{~g} / \mathrm{g}$, which is significantly higher than that of aerogels previously reported. The carbon aerogels produced have properties such as high surface area of $500 \mathrm{~m}^{2} \mathrm{~g}^{-1}$, hydrophobicity, and resistance to fire.

Cellulose nanofiber aerogel by Yao et al. [96] is used to adsorb sulfamerazine from water. The modified cellulose nanofibers aerogel, graphene oxide/cellulose nanofibers aerogel (GO/CNF) aerogel, was created using a chemical ultrasonic technique. In this analysis, by using a one-pot ultrasonic method, the grafting method was used to bond cellulose with GOs, providing a GO/CNF 3D network structure. The removal percentage of sulfamerazine from the $\mathrm{GO} / \mathrm{CNF}$ is $81.39 \%$. The aerogel is reusable and economical.

Han et al. [97] prepared and observed characterization of cellulose nanofibers and their nanocomposites with polyvinyl alcohol (PVA) using Moso bamboo culms. After the 
TABLE 3: Some adsorption capacity for the removal of different organic solvents and oils.

\begin{tabular}{|c|c|c|c|c|c|c|c|}
\hline \multirow{3}{*}{ Organic solvent/oil } & \multicolumn{7}{|c|}{ Adsorption capacity $(\mathrm{g} / \mathrm{g})$} \\
\hline & \multirow{2}{*}{ CFA [15] } & \multirow{2}{*}{ CA [90] } & \multirow{2}{*}{ MCF [91] } & \multirow{2}{*}{$\mathrm{CMF} / \mathrm{PVA} / \mathrm{GO}[92]$} & \multirow{2}{*}{ CMCA [93] } & \multicolumn{2}{|c|}{ Tubelike aerogels [17] } \\
\hline & & & & & & Stripe & Stripe + hollow \\
\hline Acetylacetone/acetone & 34 & - & - & - & - & 12 & 25 \\
\hline Chloroform & 43 & 106 & 80 & - & 84 & 22 & 42 \\
\hline Dimethylformamide & 51 & - & - & 57 & 72 & - & - \\
\hline Ethanol & 25 & 98 & - & 62 & 84 & - & - \\
\hline Heptane & 31 & 54 & - & - & - & - & - \\
\hline Corn oil & - & - & - & 58 & 44 & 14 & 26 \\
\hline Gasoline & - & - & 39 & 97 & 50 & 12 & 20 \\
\hline Toluene & 43 & - & 59 & - & 64 & 13 & 26 \\
\hline Pump oil & & 89 & 130 & 88 & 116 & - & - \\
\hline Hexane & - & 95 & 29 & - & - & - & - \\
\hline
\end{tabular}

${ }^{*} \mathrm{CFA}$, carbon fiber aerogel; CA, carbon aerogels; MCF, multifunctional carbon fiber; CNFs, cellulose nanofibers; GO, graphite powder; PVA, polyvinyl alcohol; CMCA, cellulose nanofibers/multiwalled carbon nanotubes carbon aerogel.

chemical pretreatment, the purified bamboo cellulose fibers (PBCF) that underwent ultrasonication and centrifugation and slender nanofibrils, known as bamboo cellular nanofiber (BCNF), were collected. To crosslink the BCNF suspensions, solvent exchange from water to ethanol was used, followed by solvent exchange from ethanol to tert-butanol. A chemical vapor deposition approach was used to coat the hydrophobic BCNF/PVA aerogels with methyltrichlorosilane. The silane-coated BCNF/PVA aerogels that were generated had low densities and excellent hydrophobicity. Additionally, the BCNF/PVA aerogels were composed of replicable and low-cost materials, which is an advantage for the purpose of removing aqueous $\mathrm{P}$ in various applications.

\section{Future Perspectives}

The potential advancement of bamboo adsorbents which is to combine, mix, or hybridize them with other existing types of bamboo adsorbents or with other agricultural waste adsorbents can be investigated. Research and study on these modifications of bamboo adsorbents need to be considered as they may be more efficient and probably be a strong adsorbent candidate for wastewater treatment. Further modification can be explored to achieve novel structures and improve surface properties, in order to enhance its remediation efficacy and environmental benefits, so that it can be used for the targeted application. However, there are some limitations that need to be addressed for future studies. Producing a cost-effective and sustainable adsorbent with good efficacy in adsorption has been an obstacle for practical applications. The expense of preparing an adsorbent is increased by techniques that use high temperatures. Because the majority of the published data was obtained through laboratory experiments, field studies or pilot-scale results involving bamboo adsorbents are required, as there is still a scarcity of information on this subject.

With the help of advanced technology, the efficiency of the developed adsorbent can be improved further with alternative combination materials or other treatment approaches. Bamboo-based adsorbents in the form of nano-tailored with other nanomaterials can be explored more as a nanoadsorbent showing best approaches in wastewater treatment procedures. Using response surface methodology (RSM) and artificial neural network (ANN) modelling in the study to predict the factors that affect most of the adsorbent properties and optimize the manufacturing process for bamboo-based adsorbents can be considered.

Recently, contaminant removal by hydrogel-biochar composite has been intensively conducted to improve the adsorption capacity. Hydrogel-biochar is a composite hydrogel prepared by integrating biochar into the polymeric structure of the hydrogel. Hydrogel-biochar is favorable due to its low cost and high adsorption capacity, which is suitable for contaminant removal from wastewater $[98,99]$. Previous literature shows that most of the hydrogel-biochar composites exhibit higher adsorption capacities compared to pure hydrogel. Researchers recommended focusing on composite hydrogels to improve the properties of existing hydrogels. Hydrogel-bamboo biochar should be developed for ammonia-nitrogen removal from wastewater as hydrogel-biochar as ammonianitrogen removal is still new. From other studies, composite hydrogels can exhibit a higher adsorption capacity for $\mathrm{NH}_{4}-\mathrm{N}$ removal compared to pure hydrogels.

Apart from that, studies on the removal of nutrients and anionic compounds using bamboo-based adsorbents can be carried out as there is still a lack of research on this matter. The possibility of using bamboo as a nontoxic and nutrients-containing adsorbent as a media for plant growth $[22,85]$ can be further investigated. Apart from adsorbents, using coagulants/flocculants to treat wastewater is also widely used. The natural coagulants from lignin and tannin are biodegradable for the removal of particles and organic matter in wastewater treatment $[100,101]$. It could also provide a more suitable sludge for fertilization purposes. As a lignocellulosic material, bamboo can also be used for tannin-lignin extraction for coagulants, and studies on using bamboo-based lignin can be further explored. 


\section{Conclusion}

The utilization and modification of bamboo as an activated carbon, biochar, and aerogel for wastewater treatments have been discussed. The carbonization process and activation conditions, including time, temperature, and $\mathrm{pH}$, affect the final performance of adsorbents. The activation process, either by physical or chemical activators and activated at a higher temperature, improved the surface area of the bamboo-activated carbon. Through modification, the bamboo-based biochar also possessed a larger surface area, which provides abundant surface groups with strong adsorption capacity. Bamboo-based aerogel is produced with light, high porosity, a larger inner surface area, and higher adsorption capacity after being hydrophobically modified. Advanced technology and development in aerogel through functionalization and engineered processes can potentially replace activated carbon and biochar in the future for the removal of pollutants and contaminants in wastewater. It is shown that the adsorption capacity of most of the bamboobased adsorbents is high and efficient. Some of the bamboo adsorbents also showed superior recyclability and are reusable. Therefore, it can be concluded that bamboo is a universal lignocellulosic material that can be modified and engineered into different adsorbents for different classes of pollutants and contaminants.

\section{Data Availability}

The data generated or analyzed to support the findings of this study are included within the article.

\section{Conflicts of Interest}

The authors declare that they have no conflicts of interest.

\section{Acknowledgments}

This work was supported by Universiti Malaysia Sabah (SPB0001/2020 and SDK0044/2018), and the authors also thank Universiti Malaysia Sabah for the postdoctoral fellowship awarded to Dr. Junidah Lamaming.

\section{References}

[1] V. Acevedo-García, E. Rosales, A. Puga, M. Pazos, and M. A. Sanromán, "Synthesis and use of efficient adsorbents under the principles of circular economy: waste valorisation and electroadvanced oxidation process regeneration," Separation and Purification Technology, vol. 242, p. 116796, 2020.

[2] J. Ouyang, L. Zhou, Z. Liu, J. Y. Y. Heng, and W. Chen, "Biomass-derived activated carbons for the removal of pharmaceutical mircopollutants from wastewater: a review," Separation and Purification Technology, vol. 253, p. 117536, 2020.

[3] D. R. Akwada and E. T. Akinlabi, "Economic, social and environmental assessment of bamboo for infrastructure development," in Proceedings of the International Conference on Infrastructure Development in Africa, pp. 1-15, Addis Ababa, Ethiopia, August 2016.
[4] S. M. S. D. Ramanayake, V. N. Meemaduma, and T. E. Weerawardene, "Genetic diversity and relationships between nine species of bamboo in Sri Lanka, using Random Amplified Polymorphic DNA," Plant Systematics and Evolution, vol. 269, no. 1-2, pp. 55-61, 2007.

[5] R. Sharma, J. Wahono, and H. Baral, "Bamboo as an alternative bioenergy crop and powerful ally for land restoration in Indonesia," Sustainability, vol. 10, no. 12, p. 4367, 2018.

[6] Grand View Research, Bamboos Market Size, Share \& Trends Analysis Report, by Application (Raw Materials, Industrial Products, Furniture, Shoots), by Region, and Segment Forecasts, Grand View Research, San Francisco, CA, USA, 2018.

[7] P. Chaowana, "Bamboo: an alternative raw material for wood and wood-based composites," Journal of Materials Science Research, vol. 2, no. 2, 2013.

[8] S. Youssefian and N. Rahbar, "Molecular origin of strength and stiffness in bamboo fibrils," Scientific Reports, vol. 5, no. 1, p. 11116, 2015.

[9] I. A. Kuti, B. A. Adabembe, P. A. Adeoye et al., "Production and characterization of bamboo activated carbon using different chemical impregnations for heavy metals removal in surface water," Nigerian Research Journal of Engineering and Environmental Sciences, vol. 3, no. 1, pp. 177-182, 2018.

[10] S.-F. Lo, S.-Y. Wang, M.-J. Tsai, and L.-D. Lin, "Adsorption capacity and removal efficiency of heavy metal ions by Moso and Ma bamboo activated carbons," Chemical Engineering Research and Design, vol. 90, no. 9, pp. 1397-1406, 2012.

[11] G. M. Santana, R. C. C. Lelis, E. F. Jaguaribe, R. D. M. Morais, J. B. Paes, and P. F. Trugilho, "Development of activated carbon from bamboo (bambusa vulgaris) for pesticide removal from aqueous solutions," Cerne, vol. 23, no. 1, pp. 123-132, 2017.

[12] S. Li and G. Chen, "Using hydrogel-biochar composites for enhanced cadmium removal from aqueous media," Material Science \& Engineering International Journal, vol. 2, no. 6, pp. 294-298, 2018.

[13] W. Tang, N. Cai, H. Xie et al., "Efficient adsorption removal of $\mathrm{Cd} 2+$ from aqueous solutions by $\mathrm{HNO} 3$ modified bamboo-derived biochar," IOP Conference Series: Materials Science and Engineering, vol. 729, p. 102081, 2020.

[14] Y. Wang, J. Lu, J. Wu, Q. Liu, H. Zhang, and S. Jin, “Adsorptive removal of fluoroquinolone antibiotics using bamboo biochar," Sustainability, vol. 7, no. 9, pp. 12947-12957, 2015.

[15] Y. Jiao, C. Wan, and J. Li, "Synthesis of carbon fiber aerogel from natural bamboo fiber and its application as a green high-efficiency and recyclable adsorbent," Materials \& Design, vol. 107, pp. 26-32, 2016.

[16] D. Nguyen, C. Vu, H. Vu, and H. Choi, "Micron-size white bamboo fibril-based silane cellulose aerogel: fabrication and oil absorbent characteristics," Materials, vol. 12, no. 9, p. 1407, 2019.

[17] L. Yi, Y. Xia, Z. Tan et al., "Design of tubelike aerogels with macropores from bamboo fungus for fast oil/water separation," Journal of Cleaner Production, vol. 264, p. 121558, 2020.

[18] S. S. M. Isa, M. M. Ramli, N. A. M. A. Hambali, M. M. A. B. Abdullah, and S. A. Z. Murad, "The production of Malaysia bamboo charcoal (Gigantochloa albociliata) as the potential absorbent," AIP Conference Proceedings, vol. 1885, p. 020258, 2017.

[19] N. M. Noor, R. Othman, N. M. Mubarak, and E. C. Abdullah, "Agricultural biomass-derived magnetic adsorbents: 
preparation and application for heavy metals removal," Journal of the Taiwan Institute of Chemical Engineers, vol. 78, pp. 168-177, 2017.

[20] M. N. Rashed, "Adsorption technique for the removal of organic pollutants from water and wastewater," Organic pollutants-monitoring, risk and treatment, vol. 2013, pp. 167-194, 2013.

[21] M. Rafatullah, O. Sulaiman, R. Hashim, and A. Ahmad, "Adsorption of methylene blue on low-cost adsorbents: a review," Journal of Hazardous Materials, vol. 177, no. 1-3, pp. 70-80, 2010.

[22] A. Y. Zahrim, N. N. Safie, N. Bolong et al., "Nutrients recovery processes for sewage: a short review," IOP Conference Series: Materials Science and Engineering, vol. 606, no. 1, p. 012007, 2019.

[23] A. Rossner, S. A. Snyder, and D. R. U. Knappe, "Removal of emerging contaminants of concern by alternative adsorbents,” Water Research, vol. 43, no. 15, pp. 3787-3796, 2009.

[24] N. B. Singh, G. Nagpal, and S. Agrawal, "Water purification by using adsorbents: a review," Environmental Technology \& Innovation, vol. 11, pp. 187-240, 2018.

[25] I. Ali, "New generation adsorbents for water treatment," Chemical Reviews, vol. 112, no. 10, pp. 5073-5091, 2012.

[26] R. Soni, S. Bhardwaj, and D. P. Shukla, "Various watertreatment technologies for inorganic contaminants: current status and future aspects," in Inorganic Pollutants in Water, pp. 273-295, Elsevier, Amsterdam, Netherlands, 2020.

[27] A. R. Tehrani-Bagha and T. Balchi, "Catalytic wet peroxide oxidation," in Advanced Oxidation Processes for Waste Water Treatment, Emerging Green Chemical TechnologyAcademic Press, Cambridge, MA, USA, 2018.

[28] J. Park, I. Hung, Z. Gan, O. J. Rojas, K. H. Lim, and S. Park, "Activated carbon from biochar: influence of its physicochemical properties on the sorption characteristics of phenanthrene," Bioresource Technology, vol. 149, pp. 383389, 2013.

[29] P. Grammelis, N. Margaritis, and D.-S. Kourkoumpas, “4.27 pyrolysis energy conversion systems," Comprehensive Energy Systems, vol. 4, pp. 1065-1106, 2018.

[30] P. Franco, S. Cardea, A. Tabernero, and I. De Marco, "Porous aerogels and adsorption of pollutants from water and air: a review," Molecules, vol. 26, no. 15, p. 4440, 2021.

[31] L. O. Ekebafe, M. O. Ekebafe, F. O. Akpa, G. Erhuanga, and B. W. Etiobhio, "Graft copolymerization of acrylonitrile onto delignified native bamboo (Bambusa vulgaris) cellulosic and its utilization potential for heavy metal uptake from aqueous medium," Chemical Industry and Chemical Engineering Quarterly, vol. 17, no. 2, pp. 133-140, 2011.

[32] W. Li and S. He, "Research on the utilization and development of bamboo resources through problem analysis and assessment," IOP Conference Series: Earth and Environmental Science, vol. 300, no. 5, pp. 1-6, 2019.

[33] V. Katheresan, J. Kansedo, and S. Y. Lau, "Efficiency of various recent wastewater dye removal methods: a review," Journal of Environmental Chemical Engineering, vol. 6, no. 4, pp. 4676-4697, 2018.

[34] W. Xiang, X. Zhang, J. Chen et al., "Biochar technology in wastewater treatment: a critical review," Chemosphere, vol. 252, p. 126539, 2020.

[35] M. S. Reza, C. S. Yun, S. Afroze et al., "Preparation of activated carbon from biomass and its' applications in water and gas purification, a review," Arab Journal of Basic and Applied Sciences, vol. 27, no. 1, pp. 208-238, 2020.
[36] N. Hagemann, K. Spokas, H.-P. Schmidt, R. Kägi, M. Böhler, and T. Bucheli, "Activated carbon, biochar and charcoal: linkages and synergies across pyrogenic carbon's ABCs," Water, vol. 10, no. 2, p. 182, 2018.

[37] Y. Wang, C. Liu, and Y. Zhou, "Preparation and adsorption performances of mesopore-enriched bamboo activated carbon," Frontiers of Chemical Engineering in China, vol. 2, no. 4, pp. 473-477, 2008.

[38] T. E. Odetoye, M. S. Abu Bakar, and J. O. Titiloye, "Pyrolysis and characterization of Jatropha curcas shell and seed coat," Nigerian Journal of Technological Development, vol. 16, no. 2, p. 71, 2019.

[39] S. Mahanim, I. Asma, J. Rafidah, E. Puad, and H. Shaharuddin, "Production of activated carbon from industrial bamboo wastes," Journal of Tropical Forest Science, vol. 23, no. 4, pp. 417-424, 2011.

[40] L. S. Chan, W. H. Cheung, and G. McKay, "Adsorption of acid dyes by bamboo derived activated carbon," Desalination, vol. 218, no. 1-3, pp. 304-312, 2008.

[41] Q.-S. Liu, T. Zheng, P. Wang, and L. Guo, "Preparation and characterization of activated carbon from bamboo by microwave-induced phosphoric acid activation," Industrial Crops and Products, vol. 31, no. 2, pp. 233-238, 2010a.

[42] K.-L. Chang, C.-C. Chen, J.-H. Lin et al., "Rice straw-derived activated carbons for the removal of carbofuran from an aqueous solution," New Carbon Materials, vol. 29, no. 1, pp. 47-54, 2014.

[43] V. O. Njoku, M. A. Islam, M. Asif, and B. H. Hameed, "Adsorption of 2,4-dichlorophenoxyacetic acid by mesoporous activated carbon prepared from $\mathrm{H} 3 \mathrm{PO} 4$-activated langsat empty fruit bunch," Journal of Environmental Management, vol. 154, pp. 138-144, 2015.

[44] A. Ul Haq, J. Shah, M. R. Jan, and S. ud Din, "Kinetic, equilibrium and thermodynamic studies for the sorption of metribuzin from aqueous solution using banana peels, an agro-based biomass," Toxicological and Environmental Chemistry, vol. 97, no. 2, pp. 124-134, 2015.

[45] D. Lv, Y. Liu, J. Zhou et al., "Application of EDTA-functionalized bamboo activated carbon (BAC) for $\mathrm{Pb}(\mathrm{II})$ and $\mathrm{Cu}(\mathrm{II})$ removal from aqueous solutions," Applied Surface Science, vol. 428, pp. 648-658, 2018.

[46] R. Thotagamuge, M. R. R. Kooh, A. H. Mahadi et al., "Copper modified activated bamboo charcoal to enhance adsorption of heavy metals from industrial wastewater," Environmental Nanotechnology, Monitoring \& Management, vol. 16, p. 100562, 2021.

[47] P. G. González and Y. B. Pliego-Cuervo, "Adsorption of $\mathrm{Cd}(\mathrm{II}), \mathrm{Hg}(\mathrm{II})$ and $\mathrm{Zn}(\mathrm{II})$ from aqueous solution using mesoporous activated carbon produced from Bambusa vulgaris striata," Chemical Engineering Research and Design, vol. 92, no. 11, pp. 2715-2724, 2014.

[48] E. M. Mistar, I. Hasmita, T. Alfatah, A. Muslim, and M. D. Supardan, "Adsorption of mercury(II) using activated produced from bambusa vulgaris var. striata in a fixed bed column," Sains Malaysiana, vol. 48, no. 4, pp. 719-725, 2019.

[49] H. Xiang, Z. Feng, J. Yang et al., "N-doped porous carbon derived from bamboo fiber as a high-performance adsorbent for methylene blue," Bioresources, vol. 14, no. 4, pp. 87658784, 2019.

[50] S. K. Ghosh and A. Bandyopadhyay, "Adsorption of methylene blue onto citric acid treated carbonized bamboo leaves powder: equilibrium, kinetics, thermodynamics analyses," Journal of Molecular Liquids, vol. 248, pp. 413-424, 2017. 
[51] M. Hata, Y. Amano, P. Thiravetyan, and M. Machida, "Preparation of bamboo chars and bamboo activated carbons to remove color and COD from ink wastewater," Water Environment Research, vol. 88, no. 1, pp. 87-96, 2016.

[52] C. Bouchelta, M. S. Medjram, M. Zoubida, F. A. Chekkat, N. Ramdane, and J.-P. Bellat, "Effects of pyrolysis conditions on the porous structure development of date pits activated carbon," Journal of Analytical and Applied Pyrolysis, vol. 94, pp. 215-222, 2012.

[53] Y.-J. Zhang, Z.-J. Xing, Z.-K. Duan, M. Meng Li, and Y. Wang, "Effects of steam activation on the pore structure and surface chemistry of activated carbon derived from bamboo waste," Applied Surface Science, vol. 315, pp. 279286, 2014.

[54] F. T. Ademiluyi and E. O. David-West, "Effect of chemical activation on the adsorption of heavy metals using activated carbons from waste materials," ISRN Chemical Engineering, vol. 2012, Article ID 674209, 5 pages, 2012.

[55] X. Ma, L. M. Smith, L. Cai, S. Q. Shi, H. Li, and B. Fei, "Preparation of high performance activated carbons using bamboo through one-step pyrolysis," Bioresources, vol. 14, no. 1, pp. 688-699, 2019.

[56] J. Lehmann and S. Joseph, Biochar for Environmental Management, Earthscan, London, UK, 1st edition, 2009.

[57] H. Kazemi Shariat Panahi, M. Dehhaghi, Y. S. Ok et al., "A comprehensive review of engineered biochar: production, characteristics, and environmental applications," Journal of Cleaner Production, vol. 270, p. 122462, 2020.

[58] N. N. Safie and A. Y. Zahrim, "Recovery of nutrients from sewage using zeolite-chitosan-biochar adsorbent: current practices and perspectives," Journal of Water Process Engineering, vol. 40, p. 101845, 2021.

[59] M. Gale, T. Nguyen, M. Moreno, and K. L. GilliardAbdulAziz, "Physiochemical properties of biochar and activated carbon from biomass residue: influence of process conditions to adsorbent properties," ACS Omega, vol. 6, no. 15, pp. 10224-10233, 2021.

[60] H. N. Tran, H.-P. Chao, and S.-J. You, "Activated carbons from golden shower upon different chemical activation methods: synthesis and characterizations," Adsorption Science and Technology, vol. 36, no. 1-2, pp. 95-113, 2018.

[61] N. Anderson, H. Gu, and R. Bergman, "Comparison of novel biochars and steam activated carbon from mixed conifer mill residues," Energies, vol. 14, no. 24, p. 8472, 2021.

[62] J. Wang and S. Wang, "Preparation, modification and environmental application of biochar: a review," Journal of Cleaner Production, vol. 227, pp. 1002-1022, 2019.

[63] E. L. Hernandez-Mena, A. A. B. Pécora, and A. L. Beraldo, "Slow pyrolysis of bamboo biomass: analysis of biochar properties," Chemical Engineering Transactions, vol. 37, pp. 115-120, 2014.

[64] A. Tomczyk, Z. Sokołowska, and P. Boguta, "Biochar physicochemical properties: pyrolysis temperature and feedstock kind effects," Reviews in Environmental Science and Biotechnology, vol. 19, no. 1, pp. 191-215, 2020.

[65] B. Wang, B. Gao, and J. Fang, "Recent advances in engineered biochar productions and applications," Critical Reviews in Environmental Science and Technology, vol. 47, no. 22, pp. 2158-2207, 2017.

[66] X. Yang, Y. Wan, Y. Zheng et al., "Surface functional groups of carbon-based adsorbents and their roles in the removal of heavy metals from aqueous solutions: a critical review," Chemical Engineering Journal, vol. 366, pp. 608-621, 2019.
[67] O. D. Nartey and B. Zhao, "Biochar preparation, characterization, and adsorptive capacity and its effect on bioavailability of contaminants: an overview," Advances in Materials Science and Engineering, vol. 2014, Article ID 715398, 12 pages, 2014.

[68] J. Z. Y. Tan, N. M. Nursam, F. Xia et al., "High-performance coral reef-like carbon nitrides: synthesis and application in photocatalysis and heavy metal ion adsorption," ACS Applied Materials \& Interfaces, vol. 9, no. 5, pp. 4540-4547, 2017.

[69] P. R. Yaashikaa, P. S. Kumar, S. Varjani, and A. Saravanan, "A critical review on the biochar production techniques, characterization, stability and applications for circular bioeconomy," Biotechnology Reports, vol. 28, p. e00570, 2020.

[70] A. H. Alamin and L. Kaewsichan, "Equilibrium and kinetic studies of sorption of 2.4-dichlorophenol onto 2 mixtures: bamboo biochar plus calcium sulphate (BC) and hydroxyapatite plus bamboo biochar plus calcium sulphate (HBC), in a fluidized bed circulation column," Polish Journal of Chemical Technology, vol. 18, no. 2, pp. 59-67, 2016.

[71] J. Huang, A. R. Zimmerman, H. Chen, and B. Gao, "Ball milled biochar effectively removes sulfamethoxazole and sulfapyridine antibiotics from water and wastewater," Environmental Pollution, vol. 258, p. 113809, 2020.

[72] H. Zhang, R. Xiao, R. Li, A. Ali, A. Chen, and Z. Zhang, "Enhanced aqueous $\mathrm{Cr}(\mathrm{VI})$ removal using chitosan-modified magnetic biochars derived from bamboo residues," Chemosphere, vol. 261, p. 127694, 2020.

[73] D. Huang, C. Liu, C. Zhang et al., "Cr(VI) removal from aqueous solution using biochar modified with $\mathrm{Mg} / \mathrm{Al}$-layered double hydroxide intercalated with ethylenediaminetetraacetic acid," Bioresource Technology, vol. 276, pp. 127-132, 2019.

[74] X. Wang, J. Feng, Y. Cai et al., "Porous biochar modified with polyethyleneimine (PEI) for effective enrichment of $\mathrm{U}(\mathrm{VI})$ in aqueous solution," The Science of the Total Environment, vol. 708, p. 134575, 2020.

[75] R. Fan, C.-L. Chen, J.-Y. Lin et al., "Adsorption characteristics of ammonium ion onto hydrous biochars in dilute aqueous solutions," Bioresource Technology, vol. 272, pp. 465-472, 2019.

[76] Y. Yang, X. Lin, B. Wei, Y. Zhao, and J. Wang, "Evaluation of adsorption potential of bamboo biochar for metal-complex dye: equilibrium, kinetics and artificial neural network modeling," International journal of Environmental Science and Technology, vol. 11, no. 4, pp. 1093-1100, 2014.

[77] Z. Wu, X. Wang, J. Yao et al., "Synthesis of polyethyleneimine modified $\mathrm{CoFe} 2 \mathrm{O} 4$-loaded porous biochar for selective adsorption properties towards dyes and exploration of interaction mechanisms," Separation and Purification Technology, vol. 277, p. 119474, 2021.

[78] J. Zhang, W. Lu, H. Li et al., "Polyethyleneimine-impregnated alkali treated waste bamboo powder for effective dye removal," Water Science and Technology, vol. 83, no. 5, pp. 1183-1197, 2021.

[79] Y. Zheng, A. R. Zimmerman, and B. Gao, "Comparative investigation of characteristics and phosphate removal by engineered biochars with different loadings of magnesium, aluminum, or iron," The Science of the Total Environment, vol. 747, p. 141277, 2020.

[80] W. Jia, X. Sun, Y. Gao, Y. Yang, and L. Yang, "Fe-modified biochar enhances microbial nitrogen removal capability of constructed wetland," The Science of the Total Environment, vol. 740, p. 139534, 2020. 
[81] E. Viglašová, M. Galamboš, Z. Danková et al., "Production, characterization and adsorption studies of bamboo-based biochar/montmorillonite composite for nitrate removal," Waste Management, vol. 79, pp. 385-394, 2018.

[82] Y. Qin, X. Zhu, Q. Su et al., "Enhanced removal of ammonium from water by ball-milled biochar," Environmental Geochemistry and Health, vol. 42, no. 6, pp. 1579-1587, 2020.

[83] J. Luo, X. Li, C. Ge et al., "Sorption of norfloxacin, sulfamerazine and oxytetracycline by $\mathrm{KOH}$-modified biochar under single and ternary systems," Bioresource Technology, vol. 263, pp. 385-392, 2018.

[84] C. Liang, L. C. Xiao, H. Z. Chun et al., "Environmentalfriendly montmorillonite-biochar composites: facile production and tunable adsorption-release of ammonium and phosphate," Journal of Cleaner Production, vol. 156, pp. 648-659, 2017.

[85] L. N. S. Ricky, Y. Shahril, B. Nurmin, and A. Zahrim, "Ammonia-nitrogen removal from urban drainage using modified fresh empty fruit bunches: a case study in Kota Kinabalu, Sabah," IOP Conference Series: Earth and Environmental Science, vol. 36, p. 012055, 2016.

[86] Y. Chen, Y. Wen, Q. Zhou, and J. Vymazal, "Effects of plant biomass on nitrogen transformation in subsurface-batch constructed wetlands: a stable isotope and mass balance assessment," Water Research, vol. 63, pp. 158-167, 2014.

[87] L. Zuo, Y. Zhang, L. Zhang, Y.-E. Miao, W. Fan, and T. Liu, "Polymer/carbon-based hybrid aerogels: preparation, properties and applications," Materials, vol. 8, no. 10, pp. 6806-6848, 2015.

[88] C. Wan, Y. Lu, Y. Jiao, C. Jin, Q. Sun, and J. Li, "Fabrication of hydrophobic, electrically conductive and flame-resistant carbon aerogels by pyrolysis of regenerated cellulose aerogels," Carbohydrate Polymers, vol. 118, pp. 115-118, 2015.

[89] Z.-Y. Wu, C. Li, H.-W. Liang, J.-F. Chen, and S.-H. Yu, "Ultralight, flexible, and fire-resistant carbon nanofiber aerogels from bacterial cellulose," Angewandte Chemie International Edition, vol. 52, no. 10, pp. 2925-2929, 2013.

[90] W. Yuan, X. Zhang, J. Zhao et al., "Ultra-lightweight and highly porous carbon aerogels from bamboo pulp fibers as an effective sorbent for water treatment," Results in Physics, vol. 7, pp. 2919-2924, 2017.

[91] S. Yang, L. Chen, L. Mu, B. Hao, and P.-C. Ma, "Low cost carbon fiber aerogel derived from bamboo for the adsorption of oils and organic solvents with excellent performances," RSC Advances, vol. 5, no. 48, pp. 38470-38478, 2015.

[92] Z. Xu, H. Zhou, S. Tan et al., "Ultralight super-hydrophobic carbon aerogels based on cellulose nanofibers/poly(vinyl alcohol)/graphene oxide (CNFs/PVA/GO) for highly effective oil-water separation," Beilstein Journal of Nanotechnology, vol. 9, pp. 508-519, 2018a.

[93] Z. Xu, X. Jiang, S. Tan et al., "Preparation and characterisation of CNF/MWCNT carbon aerogel as efficient adsorbents," IET Nanobiotechnology, vol. 12, no. 4, pp. 500-504, 2018 b.

[94] Y. Chen, Q. Li, Y. Li et al., "Fabrication of cellulose nanocrystal-g-poly(acrylic acid-co-acrylamide) aerogels for efficient Pb(II) removal," Polymers, vol. 12, no. 2, p. 333, 2020.

[95] H. Wang, Y. Gong, and Y. Wang, "Cellulose-based hydrophobic carbon aerogels as versatile and superior adsorbents for sewage treatment," RSC Advances, vol. 4, no. 86, pp. 45753-45759, 2014.

[96] Q. Yao, B. Fan, Y. Xiong, and C. Wang, "Adsorptive removal of sulfamerazine from water by modified cellulose nanofibers aerogel," in Proceedings of the 2016 2nd International
Conference on Advances in Energy, Environment and Chemical Engineering, Singapore, July 2016.

[97] S. Han, Q. Yao, C. Jin, B. Fan, H. Zheng, and Q. Sun, "Cellulose nanofibers from bamboo and their nanocomposites with polyvinyl alcohol: preparation and characterization," Polymer Composites, vol. 39, no. 8, pp. 2611-2619, 2018.

[98] N. Karakoyun, S. Kubilay, N. Aktas et al., "Hydrogel-biochar composites for effective organic contaminant removal from aqueous media," Desalination, vol. 280, no. 1-3, pp. 319-325, 2011.

[99] M. Sadeghi Afjeh, G. Bagheri Marandi, and M. J. ZohuriaanMehr, "Nitrate removal from aqueous solutions by adsorption onto hydrogel-rice husk biochar composite," Water Environment Research, vol. 92, no. 6, pp. 934-947, 2020.

[100] T. A. Hassan, H. T. Abdalamir, and S. H. Salah, "A novel coagulant based on lignin and tannin for bentonite removal from raw water," International Journal of Advanced Research, vol. 3, no. 2, pp. 426-442, 2015.

[101] A. Ibrahim and A. Z. Yaser, "Colour removal from biologically treated landfill leachate with tannin-based coagulant," Journal of Environmental Chemical Engineering, vol. 7, no. 6, p. 103483, 2019. 